\title{
Regeneration of Centella asiatica plants from non- embryogenic cell lines and evaluation of antibacterial and antifungal properties of regenerated calli and plants
}

\author{
Yamin Bibi ${ }^{1}$, Muhammad Zia ${ }^{2}$, Sobia Nisa', Darima Habib ${ }^{1}$, Abdul Waheed $^{3}$ and Fayyaz M Chaudhary ${ }^{1}$
}

\begin{abstract}
Background: The threatened plant Centella asiatica L. is traditionallyused for a number of remedies. In vitro plant propagation and enhanced metabolite production of active metabolites through biotechnological approaches has gained attention in recent years.

Results: Present study reveals that 6-benzyladenine (BA) either alone or in combination with 1-naphthalene acetic acid (NAA) supplemented in Murashige and Skoog (MS) medium at different concentrations produced good quality callus from leaf explants of C. asiatica. The calli produced on different plant growth regulators at different concentrations were mostly embryogenic and green. Highest shoot regeneration efficiency; 10 shoots per callus explant, from non-embryogenic callus was observed on $4.42 \mu \mathrm{M}$ BA with $5.37 \mu \mathrm{M}$ NAA. Best rooting response was observed at 5.37 and $10.74 \mu \mathrm{M}$ NAA with 20 average number of roots per explant. Calli and regenerated plants extracts inhibited bacterial growth with mean zone of inhibition 9-13 mm diameter when tested against six bacterial strains using agar well diffusion method. Agar tube dilution method for antifungal assay showed 3.2-76\% growth inhibition of Mucor species, Aspergillus fumigatus and Fusarium moliniformes.
\end{abstract}

Conclusions: The present investigation reveals that non-embryogenic callus can be turned into embryos and plantlets if cultured on appropriate medium. Furthermore, callus from leaf explant of C. asiatica can be a good source for production of antimicrobial compounds through bioreactor.

Keywords: Antimicrobial, Centella asiatica, organogenesis, plant growth regulators

\section{Background}

In recent years considerable attention has been paid to utilize eco-friendly and bio-friendly plant based products, normally secondary metabolites, for the prevention and cure of different human diseases including microbial infections [1]. Moreover, the continuous and non-organized exploitation has resulted in many plants becoming rare or extinct. So there is a dire need to set a protocol for in vitro production of plants. In view of commercial importance given to secondary metabolites, efficient production of bioactive compounds by tissue culture technology has gained popularity [2]. Secondary metabolites

\footnotetext{
* Correspondence: ziachaudhary@gmail.com

2Department of Biotechnology, Quaid-i-Azam University, Islamabad, Pakistan Full list of author information is available at the end of the article
}

often have a complex stereo structure and many of these cannot be synthesized economically on a commercial basis. To overcome this limitation, biotechnologists suggest "the use of cell and tissue culture technology rather than the whole plant for the extraction of certain secondary metabolites [3]. Antimicrobial potential of cell culture has been studied in a number of plants i.e. Sesuvium portulacastrum L, Ephedra strobiliacea, Ephedra procera, Ephedra pachyclada $[4,5]$, and reports are also available for increased metabolite production in callus culture of Calophyllum brasiliense (calanolides), Psoralea drupacea Bge (bakuchiol) and Artemisia absenthium (artemisinin) [6-8].

Centella asiatica L. commonly known as Indian pennywort belongs to family Apiaceae. Traditionally it is used

\section{C) Biomed Central}


as nervine tonic and for the treatment of asthma, hypertension, bronchitis, dropsy, skin diseases, and urethritis $[9,10]$. C. asiatica has antibacterial, antifeedant, antituberculosis, antileprotic, and antioxidant properties [11-13]. Glycosides like indocentelloside, brahmoside, brahminoside, asiaticoside and theankuniside have been isolated from this plant. Asiaticoside is used in treatment of leprosy and tuberculosis [14].

Multiplication of $C$. asiatica through shoot tip culture [15] and meristem tip culture [14] has been reported. Stimulation of asiaticoside accumulation in whole plant cultures of $C$. asiatica by elicitors including yeast extract, $\mathrm{CdCl}_{2}, \mathrm{CuCl}_{2}$ and methyl jasmonate has been studied, and methyl jasmonate achieved maximum asiaticoside production [16]. Although callus culture and regeneration of C. asiatica has already been established, the present study assessed embryogenic response of non-embryogenic callus and to evaluate the antibacterial and antifungal potential of highly proliferated calli and regenerated plants.

\section{Results and discussion}

Leaf explants of Centella asiatica developed callus at cut surfaces and subsequently covered the entire surface of explant within 15-20 days. Callogenic response was observed on all media except the media without growth regulator. Media containing low concentration of naphthalene acetic acid (NAA; $2.68 \mu \mathrm{M}$ ) or low/high concentration of 6-benzyladenine (BA; 2.21 and $17.68 \mu \mathrm{M}$ ) also was not supportive for callus induction. Green, compact and embryogenic calli were observed with $66-100 \%$ response at BA and NAA different concentrations. Most of the media showing rapid growth of callus contained both an auxin (i.e., NAA) and a cytokinin (BA). The callus produced was compact and embryogenic with variation in colour (Table 1). Combination of NAA and BA at varying levels also resulted in difference in callogenic response (Figure 1A \& 1B). Only at two combinations $(10.74 \mu \mathrm{M}$ $\mathrm{NAA}+4.42 \mu \mathrm{M}$ BA and $21.48 \mu \mathrm{M} \mathrm{NAA}+4.42 \mu \mathrm{M} \mathrm{BA})$ was the callus non-embryogenic, friable and light green to brownish green (Figure 1A). Our results contradict Patra et al. [17] who reported that addition of NAA in MS medium containing BA or kinetin decreased callus formation response. While the best callogenic response from leaf explants was observed on MS medium supplemented with BA or Kinetin along with 2,4 dichlorophenoxy acetic acid, good callus formation was not observed when media was

Table 1 Effect of growth regulators on callus induction from Centella asiatica leaf explants

\begin{tabular}{|c|c|c|c|c|}
\hline Plant Hormone & Concentration $(\mu \mathrm{M})$ & Proliferation rate & $\begin{array}{c}\text { Response } \\
\text { (\%) }\end{array}$ & Callus characteristics \\
\hline Blank & $\mathrm{NIL}$ & - & - & - \\
\hline NAA & 2.68 & - & - & - \\
\hline NAA & 5.37 & + & $75 \pm 4.2^{c}$ & Green, compact, embryogenic \\
\hline NAA & 10.74 & ++ & $66 \pm 6.7^{d}$ & Green, compact, embryogenic \\
\hline NAA & 21.48 & +++ & $100 \pm 4^{a}$ & Green, compact, embryogenic \\
\hline $\mathrm{BA}$ & 2.21 & - & - & - \\
\hline BA & 4.42 & +++ & $66 \pm 7.1^{d}$ & Green, compact, embryogenic \\
\hline BA & 8.84 & +++ & $100 \pm 3.1^{\mathrm{a}}$ & Green, compact, embryogenic \\
\hline BA & 17.68 & - & - & - \\
\hline $\mathrm{NAA}+\mathrm{BA}$ & $2.68+2.21$ & +++ & $100 \pm 3.5^{\mathrm{a}}$ & Lush green, compact, embryogenic \\
\hline $\mathrm{NAA}+\mathrm{BA}$ & $5.37+2.21$ & ++ & $100 \pm 4.6^{a}$ & Granular, light green, nonembryogenic \\
\hline $\mathrm{NAA}+\mathrm{BA}$ & $10.74+2.21$ & + & $40 \pm 8.2^{e}$ & Brownish, very small \\
\hline $\mathrm{NAA}+\mathrm{BA}$ & $21.48+2.21$ & ++ & $92 \pm 4.9^{b}$ & Compact, green, embryogenic \\
\hline $\mathrm{NAA}+\mathrm{BA}$ & $2.68+4.42$ & ++++ & $89 \pm 3.7^{b}$ & Compact, green, embryogenic \\
\hline $\mathrm{NAA}+\mathrm{BA}$ & $5.37+4.42$ & ++++ & $100 \pm 2.1^{\mathrm{a}}$ & Compact, green, embryogenic \\
\hline $\mathrm{NAA}+\mathrm{BA}$ & $10.74+4.42$ & ++ & $83 \pm 4^{c}$ & Friable, brownish green, non embryogenic \\
\hline $\mathrm{NAA}+\mathrm{BA}$ & $21.48+4.42$ & ++ & $88 \pm 2.8^{b}$ & Friable, brownish green, non embryogenic \\
\hline $\mathrm{NAA}+\mathrm{BA}$ & $2.68+8.84$ & +++ & $88 \pm 3.3^{b}$ & Compact, whitish green \\
\hline $\mathrm{NAA}+\mathrm{BA}$ & $5.37+8.84$ & ++++ & $100 \pm 2.1^{\mathrm{a}}$ & Lush green, compact, embryogenic \\
\hline $\mathrm{NAA}+\mathrm{BA}$ & $10.74+8.84$ & ++++ & $88 \pm 5^{b}$ & Lush green, compact, embryogenic \\
\hline $\mathrm{NAA}+\mathrm{BA}$ & $21.48+8.84$ & + & $88 \pm 8^{b}$ & Compact, brownish green, embryogenic \\
\hline $\mathrm{NAA}+\mathrm{BA}$ & $2.68+17.68$ & ++ & $83 \pm 7.1^{c}$ & Lush green, compact, embryogenic \\
\hline $\mathrm{NAA}+\mathrm{BA}$ & $5.37+17.68$ & ++++ & $100 \pm 3.4^{\mathrm{a}}$ & Dark green, compact, embryogenic \\
\hline $\mathrm{NAA}+\mathrm{BA}$ & $10.74+17.68$ & ++++ & $79 \pm 5.7^{c}$ & Whitish green, compact, embryogenic \\
\hline $\mathrm{NAA}+\mathrm{BA}$ & $21.48+17.68$ & +++ & $100 \pm 1.9^{a}$ & Greenish white, compact, embryogenic \\
\hline
\end{tabular}

Percent response means followed by the letter are significantly different at the 0.05 level of confidence 


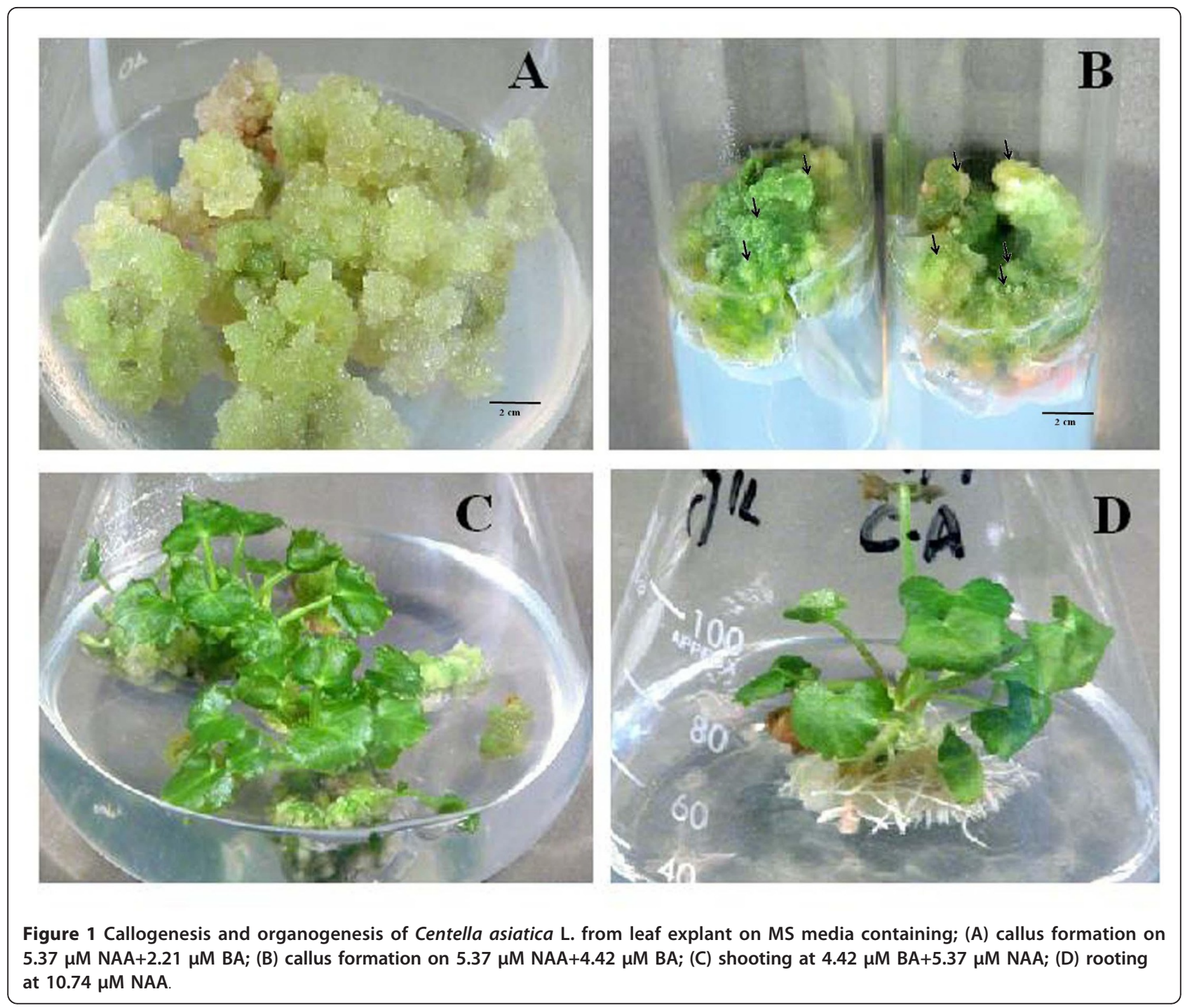

supplemented with BA and NAA [18]. Calli characteristics and induction response vary depending on explant source, explant size, media components and presence of plant growth regulator in media along with other culture conditions $[8,19]$. We observed that the embryogenic callus became hard after few days and embryo-like structures could be observed. In the present study, the embryogenic calli produced shoots after remaining on the same medium for an additional 2-4 weeks. However, due to our focus on production of shoots from non-embryogenic callus data were not recorded. The callus which failed to produce embryos (non-embryogenic) proliferated at much faster rate as compared with embryogenic calli in the same time period.

Non-embryogenic, light green and granular callus produced on $5.37 \mu \mathrm{M}$ NAA with $2.21 \mu \mathrm{M}$ BA was shifted to shooting media consisting of different hormonal combinations but response appeared only in two combinations
$(\mathrm{BA}+\mathrm{NAA} ; 2.21+5.37 \mu \mathrm{M}$ and $4.42+5.37 \mu \mathrm{M})$ after about 8 weeks (Table 2). Generally low auxin and high cytokinin concentrations in the media result in induction of shoot morphogenesis [20]. Our contrary observations can be explained by classical findings of Skoog and Miller [21] that organogenesis in tissue culture is governed by the balance of auxin and cytokinin in the media. Conversion of non embryogenic callus into embryos and organs is not well understood. However, the presence of plant hormone and its concentration sequent the cell for differentiation. Cell mass became hard and compact after few days, and dome-like structures could be observed on the surface presenting formation of embryos. Fruthermore, long time culture of callus on same media produces embryos although the response remains low [22]. The embryogenic callus produced greater number of shoots in less time period (data not shown). Conversion of dome-like structures (in embryogenic callus) into shoots 
Table 2 Effect of growth regulators on shoot regeneration from non-embryogenic callus of Centella asiatica

\begin{tabular}{cccc}
\hline Plant hormone & $\begin{array}{c}\text { Concentration } \\
(\boldsymbol{\mu} \mathbf{M})\end{array}$ & $\begin{array}{c}\text { Response } \\
(\%)\end{array}$ & Number of Shoots per callus \\
\hline BA & 0 & 0 & 0 \\
BA & 4.42 & 0 & 0 \\
BA & 8.84 & 0 & 0 \\
BA & 17.68 & 0 & 0 \\
BA+NAA & $2.21+5.37$ & 50 & $4 \pm 2.5$ \\
BA+NAA & $4.42+5.37$ & 0 & $10 \pm 6.1$ \\
BA+NAA & $8.84+5.37$ & 0 & 0 \\
BA+NAA & $17.68+5.37$ & 0 & 0 \\
Kin+NAA & $4.65+5.37$ & 0 & 0 \\
Kin+NAA & $9.29+5.37$ & 0 & 0 \\
Kin+NAA & $23.23+5.37$ & & 0 \\
\hline
\end{tabular}

over hormone dependent maturation has been studied extensively in many plants including C. asiatica [18]. Maximum 5.3 shoots per node with $91 \%$ efficiency was observed through direct shoot regeneration from nodal segments of C. asiatica on BA- and NAA- containing medium [14]. In the present study, when the calli remained on the same medium for long time, a maximum of $10 \pm 6.1$ shoots were observed.

Regenerated shoots were green, leafy and multiple as shown in Figure 1C. The shoots were separated and transferred to rooting medium to form complete plants. Best rooting response (20 roots per plantlet) was observed in the medium containing high concentration of NAA $(5.37 \mu \mathrm{M}$ and $10.74 \mu \mathrm{M})$ after 20 days (Table 3$)$. Roots were white and thin as shown in Figure 1D. Patra et al. [17] also observed the same rooting response with NAA in C. asiatica.

Rooted plantlets were separated from medium washed and extracted in methanol. Highly proliferated calli on $\mathrm{NAA}+\mathrm{BA}(10.74+4.42 \mu \mathrm{M}$ and $5.37+17.68 \mu \mathrm{M}$, respectively) were also extracted in methanol. Dried extracts were tested for antibacterial activity. Callus extracts were active against all six tested organisms. Callus extracts showed maximum activity against Pseudomonas picketii with mean zone of inhibition $15 \mathrm{~mm}$. The calli proliferated on high concentration of BA and low NAA $(10.74+4.42 \mu \mathrm{M})$ was more active against Escherichia coli while it showed equal zone of inhibition against
Micrococcus leutus and Bacillus subtilis as compared with calli regenerated/proliferated on low BA and high NAA. Shahid et al. [23] also reported that calli extract of Saraca asoca were more active against Gram negative and Gram positive bacteria as compared with whole plant extract while Landa et al. [24] concluded that the extracts of Nigella species calli tested exhibited significant anti-microbial activity, especially against Bacillus cereus, Staphylococcus aureus and Staphylococcus epidermidis.

Regenerated plant extracts were active against all strains except $P$. picketii, and showed equal or lower activity compared to callus extracts against all strains except $E$. coli (Figure 2). The maximum activity shown by regenerated plants extract was against $E$. coli with mean zone of inhibition $14 \mathrm{~mm}$. This result contradicts previous findings of Panthi and Chaudhary [25] related to antibacterial activity of in vivo plants of $C$. asiatica which showed activity against many strains but not E. coli. Also, Ullah et al. [26] reported inhibition zone up to $15 \mathrm{~mm}$ against some bacteria by different fractions of $C$. asiatica extract. These differences might be due to different culture conditions such as concentrations of growth regulators which affect active metabolite yield and hence difference in bioactivities [27].

Dried extracts were also tested for antifungal activity. Both the callus extracts as well as regenerated plants extract were active against all three tested organisms, and

Table 3 Rooting response from Centella asiatica regenerated shoots on different hormonal concentrations

\begin{tabular}{cccc}
\hline Plant hormone & Concentration $(\mu \mathrm{M})$ & Response (\%) & No of roots per shoot \\
\hline NAA & 2.68 & 0 & $0 \pm 0$ \\
NAA & 5.37 & 100 & $20 \pm 0.8^{\mathrm{a}}$ \\
NAA & 10.74 & 100 & $20 \pm 0.5^{\mathrm{a}}$ \\
IBA & 2.46 & 0 & $0 \pm 0$ \\
IBA & 4.92 & 100 & $7 \pm 0.6^{\mathrm{b}}$ \\
IBA & 9.84 & 50 & $3 \pm 0.2^{c}$ \\
\hline
\end{tabular}

Means number of roots per shoot followed by the letter are significantly different at the 0.05 level of confidence 


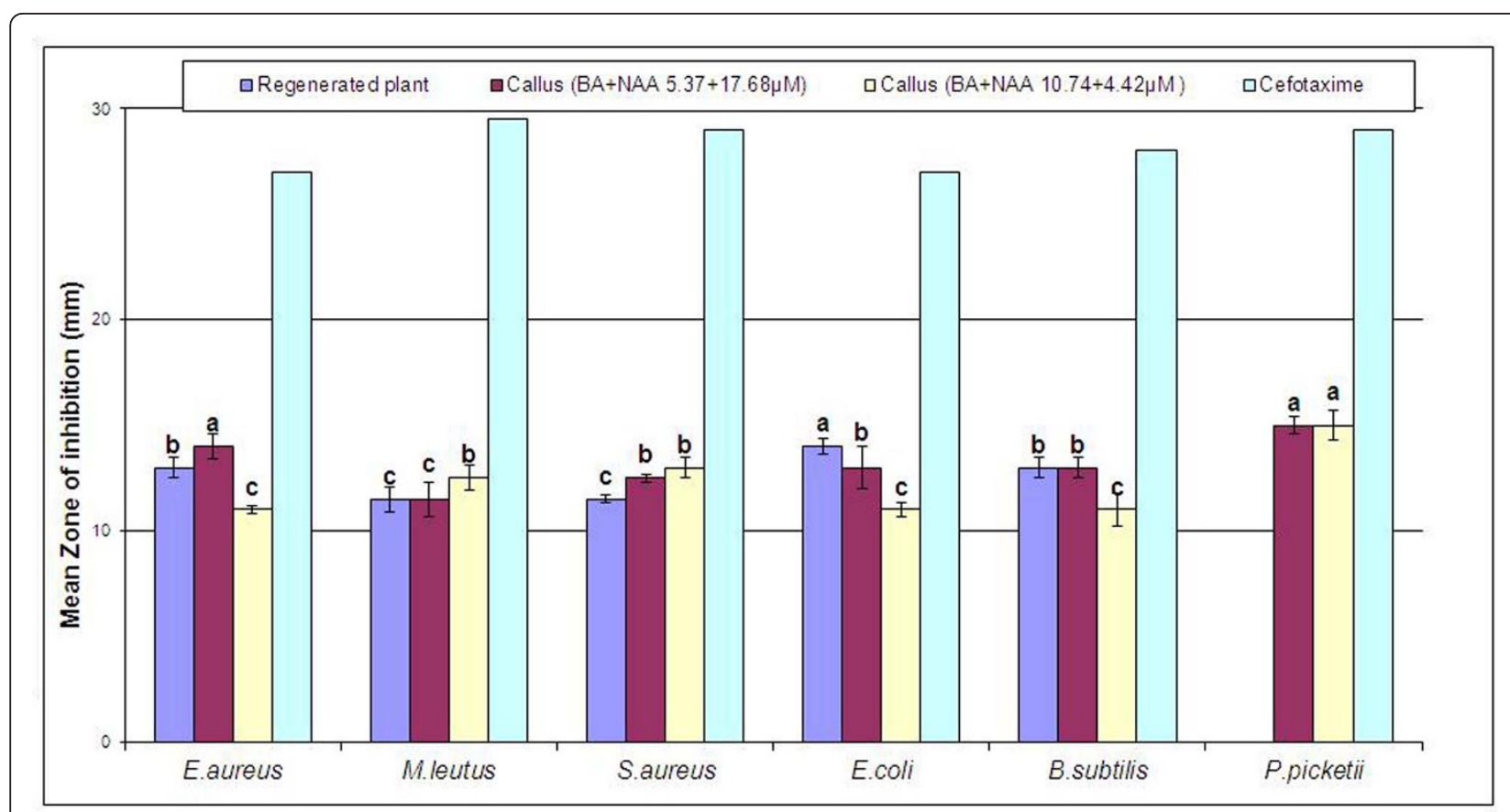

Figure 2 Antibacterial activity of regenerated plants and callus of Centella asiatica L. Results are average of triplicate. Letters on bars represent statistical difference in values (LSD) at the 0.05 level of confidence.

maximum activity was observed against Aspergillus fumigatus with inhibition of $73.4 \%$ and $76.7 \%$. Regenerated plant extract showed less activity compared with callus extracts against all strains except Mucor species (Figure 3). Though, production of bioactive metabolites in cell or callus culture is usually low as compared to wild grown plants [28]. However plant growth regulators may triggers different biochemical pathways in cell, result in enhanced production of metabolites. In present study near about equal activities were observed by calli extracts as compared with reported bioactivities of $C$. asiatica plant extract [26].

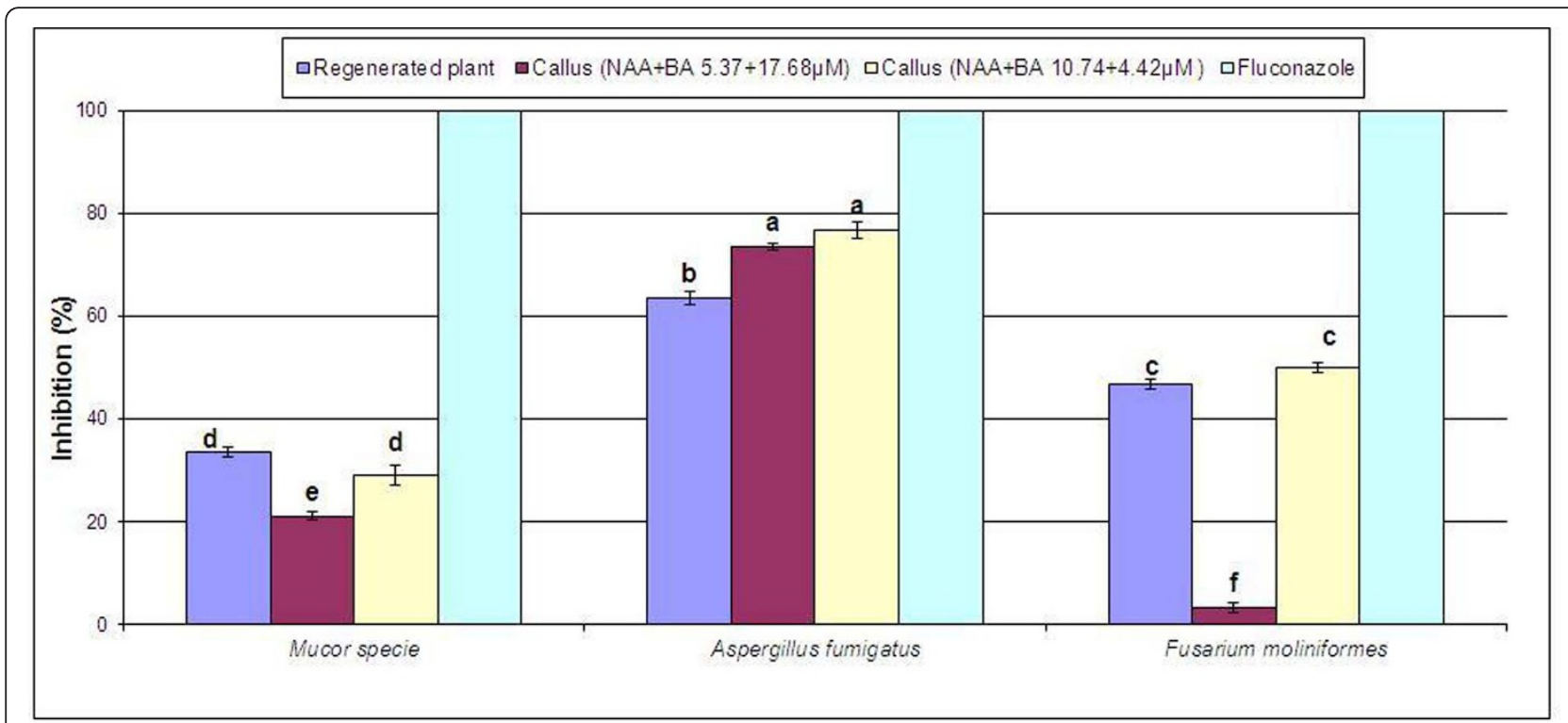

Figure 3 Antifungal activity of regenerated plants and callus of Centella asiatica L. Results are average of triplicate. Letters on bars represent statistical difference in values (LSD) at the 0.05 level of confidence. 


\section{Conclusions}

In conclusion, Centella asiatica non-embryogenic callus can be converted to embryogenic and shoots when cultured on appropriate concentrations of BA and NAA in MS medium. Both the regenerated plant and callus extracts inhibited bacterial and fungal growth. Therefore, active metabolites produced through callus might serve as an alternative source of bioactive compounds, in order to reduce the pressure on wild stocks.

\section{Methods}

\section{Plant material}

Plants of Centella asiatica were collected from the bank of Rawal Dam Islamabad Pakistan. A voucher specimen was deposited in the Herbarium of Quaid-i-Azam University Islamabad Pakistan. Plants were dipped in 5\% detergent solution (Max v/v) for $5 \mathrm{~min}$ and then thoroughly washed under running tap water for $30 \mathrm{~min}$. Under aseptic conditions, leaves were separated from stems and surface sterilized in $0.1 \%(\mathrm{w} / \mathrm{v})$ mercuric chloride solution for 1-2 min. After 4-5 rinses with sterilized distilled water, leaves were placed on sterilized filter papers to remove excess moisture. Leaves were cut into small segments of $8 \mathrm{~mm}^{2}$ to be used as explants.

\section{Callogenesis}

Basal Murashige and Skoog (MS) media [29] supplemented with different concentrations of 6-benzyladenine (BA; 2.21$17.68 \mu \mathrm{M}$ ) and nephthalene acetic acid (NAA; 2.68-21.48 $\mu \mathrm{M})$ either alone or in combination were used for callus induction from leaf explant of $C$. asiatica. The $\mathrm{pH}$ of media was adjusted at 5.7 with $0.1 \mathrm{~N} \mathrm{HCl}$ and $\mathrm{NaOH}$ before autoclaving. Sucrose (3\%) was added as carbon source and Nobel agar (0.7\%) as solidifying agent. A volume of 40-50 $\mathrm{ml}$ was dispensed in magenta jars or $100 \mathrm{ml}$ conical flasks. The flasks/jars containing media were sterilized under 15 psi pressure at $121^{\circ} \mathrm{C}$ for $20 \mathrm{~min}$. Under aseptic conditions leaf explants were inoculated on the surface of media. The flasks were incubated at $25^{\circ} \mathrm{C}$ and $16 / 8$ light dark period in a growth room. The test was performed in triplicate; each replicate contained 10 explants and data were recorded after 30 days of inoculation.

Callus cultures were maintained on MS medium containing same growth regulators at $25^{\circ} \mathrm{C}$ with a daily photoperiod of $16 \mathrm{~h}$. In order to produce enough biomass, calli were sub-cultured on monthly basis on the fresh medium. Phenotypic callus characteristics such as colour, friability and proliferation rate were assessed at every cycle during the maintenance stage.

\section{Organogenesis}

To determine shooting response, non-embryogenic callus produced on MS medium containing $5.37 \mu \mathrm{M}$ NAA and $2.21 \mu \mathrm{M}$ BA was selected. The callus was granular (scattered cells), friable and no dome-like structures were observed which appeared to be non-embryogenic under microscopic examination. The callus was transferred to shooting medium (MS) supplemented with $3 \%$ sucrose and BA (0-17.68 $\mu \mathrm{M})$, NAA $(5.37 \mu \mathrm{M})$, and Kinetin (Kin; 4.65-23.23 $\mu \mathrm{M})$ either alone or in combinations. The $\mathrm{pH}$ was maintained at 5.7 and the media was solidified by adding $0.7 \%$ Nobel agar. These cultures were maintained at $25^{\circ} \mathrm{C}$ with $16 \mathrm{~h}$ daily photoperiod. The explants were transferred on fresh medium after 2-3 weeks. The test was performed in triplicate. Each replicate contained six explants, and data were recorded after 60 days of culture.

When heights attained 3-4 cm, the shoots transferred to rooting medium composed of MS medium supplemented with different concentrations of NAA $(2.68-10.74 \mu \mathrm{M})$ and indol 3-butyric acid (IBA; 2.46-9.84 $\mu \mathrm{M})$ ). The medium was also supplemented with $3 \%$ sucrose, $0.7 \%$ Nobel agar and the $\mathrm{pH}$ was adjusted at 5.7. The test was performed in triplicate. Each replicate contained six explants, and the data were recorded after 20 days of culture. The rooted plants were washed under running tap water to remove excess media and transferred to vermiculite-containing pots. The pots were covered with transparent polythene bags to retain humidity. The plants were watered with Hogland solution when required. After one week, the polythene bags were gradually removed, and plants were transferred to pots containing peat moss and clay (1:1) and shifted to green house.

\section{Extraction}

Regenerated whole plants (34 g FW) and proliferated calli (47 g FW) on two hormonal combinations (NAA+BA; $10.74+4.42 \mu \mathrm{M}$ and $5.37+17.68 \mu \mathrm{M})$ were ground in 100 $\mathrm{ml}$ methanol and maintained at room temperature for seven days. The extract was subsequently filtered through Whatman filter paper No.1. The residue was again dipped in methanol for additional seven days. Finally, the extracts were combined and concentrated using rotary evaporator at low pressure. Obtained plant and callus extracts $(2 \mathrm{~g}$ and $1.3 \mathrm{~g}$, respectively) were subjected for antimicrobial potential.

\section{Antibacterial activity}

Bacterial strains used to assess antimicrobial activity were Enterococcus aureus, Staphylococcus aureus, Micrococcus leutus, Escherichia coli, Bacillus subtilis and Pseudomonas picketii. Stock cultures were maintained on nutrient agar slants at $4^{\circ} \mathrm{C}$ and then subcultured in nutrient broth at $37^{\circ} \mathrm{C}$ prior to antibacterial test. Dried extracts of callus and plants at the concentration $25 \mathrm{mg} / \mathrm{ml}$ were tested for antibacterial activity using agar well diffusion method [30]. Cefotaxime at a concentration of $2 \mathrm{mg} / \mathrm{ml}$ was used as positive control. Pure dimethyl sulfoxide ( $99.9 \%$ DMSO) solvent was used as negative control. Nutrient 
agar medium was prepared by suspending $20 \mathrm{~g} / \mathrm{l}$ nutrient agar (Merck) and autoclaved. When the medium cooled down at $45^{\circ} \mathrm{C}$, it was seeded with $10 \mathrm{ml}$ of $24 \mathrm{~h}$ old bacterial culture containing approximately $10^{4}-10^{6}$ colony forming units per ml. Petri plates were prepared by pouring $75 \mathrm{ml}$ of seeded nutrient agar per plate. Wells were made with $8 \mathrm{~mm}$ cork borer, and each well was sealed with $20 \mu \mathrm{l}$ of molten nutrient agar. Experimental plates were incubated at $37^{\circ} \mathrm{C}$ for $24 \mathrm{~h}$ and zones of inhibition $(\mathrm{mm})$ were measured and compared with standard antibiotic zone of inhibition.

\section{Antifungal activity}

Fungal strains used were Mucor species, Aspergillus fumigatus and Fusarium moliniformes. Stock cultures were maintained on nutrient agar slants at $4^{\circ} \mathrm{C}$ and then subcultured in Sabouraud Dextrose agar slants at $28^{\circ} \mathrm{C}$ seven days prior to antifungal assay.

The antifungal activity of calli and regenerated plants extracts was determined using the agar tube dilution method [31]. Sabouraud dextrose agar (Merck) was dissolved and dispensed as $4 \mathrm{ml}$ per screw capped tube and autoclaved at $121^{\circ} \mathrm{C}, 15 \mathrm{psi}$ pressure for $20 \mathrm{~min}$. The tubes were allowed to $\mathrm{cool}$ at $50^{\circ} \mathrm{C}$, and $100 \mu \mathrm{l}$ of plant extract was poured from the stock solution $(20 \mathrm{mg} / \mathrm{ml}$ in DMSO) to attain a final concentration of $50 \mu \mathrm{g} / \mathrm{ml}$. Fluconazole $(12 \mathrm{mg} / \mathrm{ml})$ was used as positive control, DMSO was a negative control. The tubes were shaken well and allowed to solidify at slanting position at room temperature. The tubes were then inoculated with $4 \mathrm{~mm}$ piece of inoculum and incubated at $28^{\circ} \mathrm{C}$ for 7 days. Growth was determined by measuring linear growth $(\mathrm{mm})$, and growth inhibition was calculated with reference to negative control using following formula

Percentage inhibition of fungal growth $=100-[$ Linear growth in test tube $(\mathrm{mm}) /$ Linear growth in control $(\mathrm{mm})] \times 100$

\section{Statistical analysis}

To analyze callogenic and organogenic response, the tests were performed in triplicate for each hormone concentration/combination. Each replicate contained 10 explants for callogenesis and six explants for organogenesis (shooting and rooting separately). Callogenic data were recorded after 30 days of culture and analysed using Least Significant Difference (LSD) at probability level $\mathrm{p}<0.05$. Shooting response was analyzed for average number of shoots per explant after 60 days of culture. Rooting data recorded after 20 days of culture were analysed for average number of roots per plantlet by $\mathrm{t}$-test at probability level $\mathrm{p}<0.05$ for least significant difference.

The antibacterial and antifungal tests were performed in triplicate for each microorganism. The means of average zone of inhibition in antibacterial assay and growth inhibition for antifungal assay were further analysed using LSD at probability level $\mathrm{p}<0.05$.

\section{List of abbreviations}

BA: 6-benzyladenine; DMSO: dimethyl sulfoxide; IBA: indole 3-butyric acid; Kin: kinetin; LSD: Least significant difference; MS: Murashige and Skoog; NAA: nephthalene acetic acid

\section{Acknowledgements}

We are thankful to Higher Education Commission (HEC) Pakistan for provision of grant to perform this research work.

\section{Author details}

'Department of Microbiology, Quaid-i-Azam University, Islamabad, Pakistan. ${ }^{2}$ Department of Biotechnology, Quaid-i-Azam University, Islamabad, Pakistan. ${ }^{3}$ School of Pharmacy and Chemistry, Kingston University, UK.

\section{Authors' contributions}

$\mathrm{YB}, \mathrm{SN}, \mathrm{DH}$ and $\mathrm{AW}$ carried out the experimental part such as callogenesis, organogenesis, preparation of inoculums, antibacterial and antifungal assay. MZ evaluated the results, and wrote the manuscript. FMC supervised the work and corrected the manuscript. Authors read and approved the final manuscript.

\section{Competing interests}

The authors declare that they have no competing interests.

Received: 5 July 2011 Accepted: 12 October 2011

Published: 12 October 2011

\section{References}

1. Dubey NK, Kumar R, Tripathi P: Global promotion of herbal medicines: Indian opportunity. Curr Sci India 2004, 80:37-41.

2. Vaniserce M, Lee C, Nalawade SN, Lin CY, Tasy H: Studies on the production of some important secondary metabolites from medicinal plants by plant tissue culture. Bot Bull Acad Sinica 2004, 45:1-22

3. Smetanska I: Production of Secondary Metabolites Using Plant Cell Cultures. Adv Biochem Eng Biotechnol 2008, 111:187-228.

4. Ali P, Elmira S, Katayoun J: Comparative study of the antibacterial, antifungal and antioxidant activity and total content of phenolic compounds of cell cultures and wild plants of three endemic species of Ephedra. Molecules 2010, 15:1668-1678.

5. Asmathunisha N, Kathiresan K, Anburaj R, Alikunhi NM: Synthesis of antimicrobial silver nanoparticles by callus and leaf extracts from saltmarsh plant, Sesuvium portulacastrum L. Colloids Surfaces B 2010, 79:488-493.

6. Bernabe-Antonio A, Estrada-Zuniga ME, Buendia-Gonzalez L, Reyes-Chilpa R, Chavez-Avila VM, Cruz-Sosa F: Production of anti-HIV-1 calanolides in a callus culture of Calophyllum brasiliense (Cambes). Plant cell Tiss Org 2010, 103:33-40.

7. Kateryna L, Valeria B, Yuriy S, Ingham JL, Valeria P, Olena K, Evgenija P, Mykola K: Production of bakuchiol by in vitro systems of Psoralea drupacea Bge. Plant Cell Tiss Org 2010, 101:99-103.

8. Zia M, Mannan A, Chaudhary MF: Effect of growth regulators and amino acids on artemisinin production in the callus of Artemisia absinthium. Pak J Bot 2007, 39:799-805.

9. Kakkar KK: Mandukaparni-medicinal uses and therapeutic efficacy. Indian Drug 1998, 26:92-97.

10. Lucas R: Natures medicine. Prentice Hall; 1979.

11. Chakraborty T, Sinha BS, Sukul NC: Preliminary evidence of antifilarial effect of Centella asiatica on canine dirofilariasis. Fitoterapia 1996, 67:110-112.

12. Srisvastava R, Shukla YN, Kumar S: Chemistry and Pharmacology of Centella asiatica: a review. J Med Aromatic Plant Sci 1997, 19:1049-1056.

13. Winston D, Maimes S: Adaptogen: Herbs for Strength, Stamina and Stress Relief. Healing Arts Press; 2007, 226-227.

14. Tiwari KN, Sharma NC, Tiwari V, Singh BD: Micropropagation of Centella asiatica (L.), a valuable medicinal herb. Plant Cell Tiss Org 2000, 63:179-185. 
15. Nath S, Alak KB: In vitro method for propagation of Centella asiatica (L) Ur Lucas ban by shoot tip culture. J Plant Biochem Biotechnol 2003, 12:167-169.

16. Kim OT, Kim MY, Hong MH, Ahn JC, Hwang B: Stimulation of asiaticoside accumulation in the whole plant cultures of Centella asiatica (L.) Urban by elicitors. Plant Cell Rep 2004, 23:339-344.

17. Patra A, Rai B, Rout GR, Das P: Successful plant regeneration from callus cultures of Centella asiatica (Linn.) Urban. Plant Growth Regul 1998, 24:13-16.

18. Martin KP: Plant regeneration through somatic embryogenesis in medicinally important Centella asiatica L. In Vitro Cell Dev Biol PI 2004, 40:586-591.

19. Zia M, Riaz-Ur-Rehman, Chaudhary MF: Hormonal regulation for callogenesis and organgenesis of Artemisia absinthium L. Afr J Biotechnol 2007, 6:1874-1878.

20. Flick CE, Evans DA, Sharp WR: Organogenesis. In Handbook of plant cell culture. Volume I. Edited by: Evans DA, Sharp WR, Ammirato PV, Yamada Y. MacMillan, New York; 1983:13-81.

21. Skoog F, Miller CO: Chemical regulation of growth and formulation in plant tissues cultured in vitro. In The Biological Action of Growth Substances. Edited by: Porter HK. Cambridge University Press; 1957:118-131.

22. Chakravarty B, Goswami BC: Plantlet regeneration from long-term callus cultures of Citrus acida Roxb. and the uniformity of regenerated plants. Sci Hortic-Amstradam 1999, 82:159-169.

23. Shahid M, Anwar S, Abida M, Anis M: Antibacterial activity of aerial parts as well as in vitro raised calli of the medicinal plant Saraca asoca (Roxb.) de Wilde. Can J Microbiol 2007, 53:75-81.

24. Landa P, Marsik P, Vanek T, Rada V, Kokoska L: In vitro anti-microbial activity of extracts from the callus cultures of some Nigella species. Bio Bratisl 2006, 61:285-288.

25. Panthi MP, Chaudhary RP: Antibacterial activity of some selected folklore medicinal plants from West Nepal. Sci World 2006, 4:4.

26. Ullah MO, Sultana S, Haque A, Tasmin S: Antimicrobial, Cytotoxic and ntioxidant Activity of Centella asiatica. Eur J Sci Res 2009, 30:260-264

27. Jiao B, Nobuhide I, Junichi S, Mutumi K: Taxoids and Abietanes from callus cultures of Taxas cuspidata. J Nat Prod 2005, 68:497-501.

28. Shimomura K, Kitazawa T: Tashinone production in adventitious roots and regenerates of Salvia miltiorrhiza. J Nat Prod 1991, 54:1583-1587.

29. Murashige T, Skoog F: A revised medium for rapid growth and bioassays with tobacco tissue cultures. Physiol Plant 1962, 15:473-497.

30. Bibi Y, Nisa S, Waheed A, Zia M, Sarwar S, Ahmed S, Chaudhary MF: Evaluation of Viburnum foetens for anticancer and antibacterial potential and phytochemical analysis. Afr J Biotechnol 2010, 9:5611-5615.

31. Fatima N, Zia M, Riaz-Ur-Rehman, Rizvi ZF, Ahmad S, Mirza B, Chaudhary MF: Biological activities of Rumex dentatus L: Evaluation of methanol and hexane extracts. Afr J Biotechnol 2009, 8(24):6945-6951.

doi:10.1186/1754-1611-5-13

Cite this article as: Bibi et al:: Regeneration of Centella asiatica plants from non- embryogenic cell lines and evaluation of antibacterial and antifungal properties of regenerated calli and plants. Journal of Biological Engineering 2011 5:13.

\section{Submit your next manuscript to BioMed Central and take full advantage of:}

- Convenient online submission

- Thorough peer review

- No space constraints or color figure charges

- Immediate publication on acceptance

- Inclusion in PubMed, CAS, Scopus and Google Scholar

- Research which is freely available for redistribution

Submit your manuscript at www.biomedcentral.com/submit
Biomed Central 